\title{
Frost Depth Prediction in North and South of Salang Highway, Afghanistan
}

\author{
M. Salem Hussaini' ${ }^{1}$ M. Zia Jamal ${ }^{2}$, Zamen Jafari ${ }^{3}$ \\ Department of Engineering Geology \& Hydrogeology, Kabul Polytechnic University, Kabul, Afghanistan ${ }^{1,2,3}$
}

\begin{abstract}
Nowadays, Salang highway is the major mountain pass connecting northern Afghanistan to Kabul province and southern Afghanistan. The subject of this research is to predict the frost penetration depth in north and south of Salang Highway. In order to reach this goal, field and laboratory soil data from 18 trial pits were collected and evaluated. Then Modified Berggren equation and Rajabei \& Baladi formula were applied to predict frost penetration depth. The result of this study shows that average frost penetration depth in the south of Salang highway is $138(\mathrm{~cm})$ and it is $148(\mathrm{~cm})$ in the north of the highway. It is concluded that deeper frost penetration depth in the north part is because of more dry density and more thermal properties of soils with comparison to the south part. A correlation formula is developed between dry density of soil and predicted frost depth which makes it possible to predict maximum frost depth in Salang area and also other areas with similar geographic and climate condition.
\end{abstract}

Keywords: Frost depth, Salang highway, soil thermal properties, modified Berggren equation, dry density

\section{INTRODUCTION}

Salang highway is nowadays the major mountain pass connecting northern Afghanistan to Parwan province, with onward connections to Kabul province and southern Afghanistan (Fig. 1). Salang Highway (87 km) was built in the 1960 's by the former Soviet Union. It carries most of the cross-Hindu Kush traffic, which is typically between 4,500 and 9,000 vehicles a day. It has 7 meter width with only one lane in each direction. Its highest point is at 3,400 meters altitude where a tunnel ( $2.8 \mathrm{~km}$ long) crosses under the snow-capped mountain peaks. When it was built, Salang tunnel was the world's highest road tunnel. The quality of the original highway construction was very good, with asphalt concrete pavement in the lower sections of the road and a very solid concrete pavement in the higher road sections above 2,500 meters altitude. But ever-increasing traffic volumes, heavier vehicles using snow chains in winter, many heavy military trucks with steel-spike studded tires that quickly wear down pavements and the lack of proper maintenance eventually lead to a serious deterioration of the road, especially in the higher sections that are exposed to extreme climate.

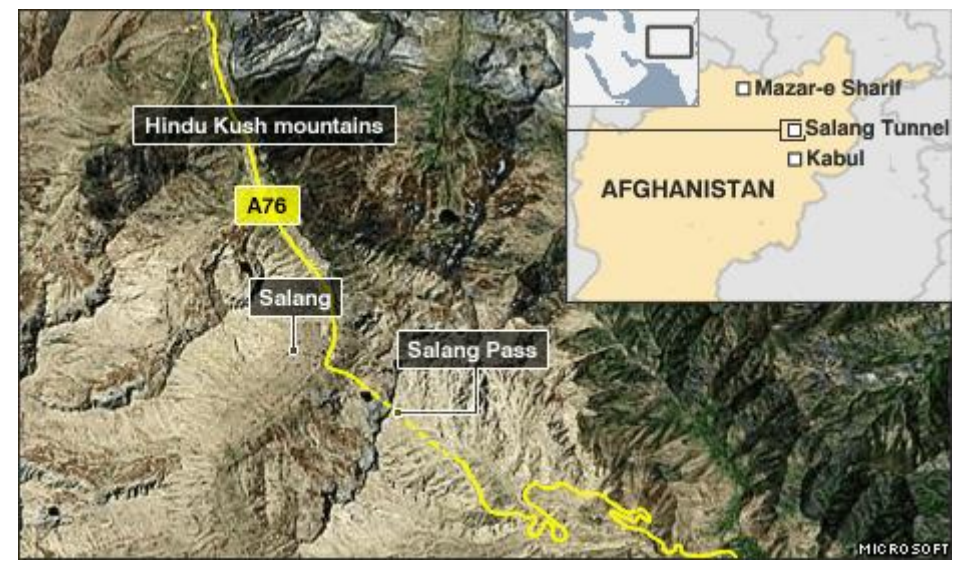

Fig. 1 General location of Salang highway

Recently several rehabilitation and repairing works have been carrying out on the road pavement and other structures in Salang highway but there is no available information about frost penetration depth along this highway. Maximum frost depth can be usually estimated through local experiences or available maps. However, using general maps which covers large areas is not recommended, and local instructions, local engineering practices and technical experiences should be applied to predict frost depth in the interest area. This study evaluates the effective parameters on the frost penetration depth and then predicts frost penetration depth based on the suggested formulas and models in the literatures. 


\section{International Advanced Research Journal in Science, Engineering and Technology}

Vol. 7, Issue 5, May 2020

Building footings should be placed below the frost line because of possible frost heave of the buildings and also alternate freezing and thawing of the soil tends to maintain it in an unconsolidated or loose state [1]. Thermal condition of soils such as frost depth is one of the important meteorological indexes in agriculture, construction, infrastructures, drainages and water supply networks [8].

The depth of frost action depends on the air temperature below freezing and duration, surface cover, soil thermal conductivity, permeability and soil water content [16]. Two common types of damage related to frost are: (1) freezing of water in cracks, and (2) formation of ice lenses. In many cases, deterioration or damage is not evident until the frost has melted. In these instances, it may be difficult for the geotechnical engineer to conclude that frost was the primary cause of the deterioration [2].

\section{MATERIAL AND METHODS}

To be able to calculate frost depth, two groups of information are necessary: (1) thermal characteristics of ground material and (2) climate conditions.

Thermal characteristics of soil are thermal conductivity, volumetric heat capacity and latent heat of fusion of soilmoisture. These values depend upon grain-size distribution, density, and moisture content of the soils.

The methods of calculation related to the climate conditions discussed by the authors are based upon the freezing index which is the average air temperature during frost penetration multiplied by its duration in days. Also it is determined by the establishment of the difference between the maximum and the minimum of the curve representing the cumulative sum of daily mean temperature [14].

Design freezing index should be the average air freezing index of the three coldest winters in the latest 30 years of record. If 30 years of record are not available, the air freezing index for the coldest winter in the latest 10-year period may be used [17].

Several methods have been suggested for determination of freezing index. Equation (1) is applied in this study to obtain freezing index [6].

Which:

$$
F=\left[\left(\sum T_{\text {month }}\right) * N i\right], \quad T_{\text {month }}<0
$$

$\mathrm{F}=$ freezing index

$\mathrm{T}_{\text {month }}=$ average monthly temperature less than zero (Celsius)

$\mathrm{Ni}=$ number of days in month.

To predict the frost penetration depth, thermal characteristics of soil material are also required. The basic thermal properties of soils and other construction materials are specific heat, thermal conductivity and volumetric latent heat of fusion. Other terms used in heat-flow calculations are derived from these data.

Specific heat of most dry soils near the freezing point is assumed to be constant at the value of $0.17\left(\mathrm{Btu} / \mathrm{lb}\right.$. $\left.{ }^{\circ} \mathrm{F}\right)$. The thermal conductivity of soils is dependent upon a number of factors: density, moisture content, particle shape, temperature, solid and liquid and vapor constituents, whether frozen or unfrozen.

We used dry density and moisture content of soil obtained from soil investigation and determined average thermal conductivity for frozen and unfrozen conditions from figure 1-2 and 2-2 in [17].

An average value from frozen and unfrozen conditions was calculated by Equation (2) which gives a more reasonable result.

$$
K_{\text {avg }}=\frac{1}{2}\left(K_{u}+K_{f}\right)
$$

Another thermal parameter of soils is volumetric heat (C) which was obtained from Equation (3) and (4) for frozen and unfrozen conditions, respectively [5].

$$
\begin{aligned}
& C_{u}=\gamma_{d}\left(0.17+\frac{w}{100}\right) \\
& C_{f}=\gamma_{d}\left(0.17+\frac{(0.5) w}{100}\right)
\end{aligned}
$$

Volumetric latent heat of fusion is quantity of heat required to melt the ice (or freeze the water) in a unit volume of soil without a change in temperature. This parameter was obtained from Equation (5).

$$
L=1.434 \omega \gamma_{d}
$$

Where:

$\omega=$ moisture content

$\gamma_{\mathrm{d}}=$ dry unit weight $\left(\mathrm{lb}\right.$ per $\left.\mathrm{ft}^{3}\right)$ 


\section{International Advanced Research Journal in Science, Engineering and Technology}

Vol. 7, Issue 5, May 2020

Several methods have been proposed and developed in the literatures to calculate frost penetration depths. One of those is proposed by Mc Koewn which is shown in Equation (6).

$$
D=\lambda *(A F I)^{1 / 2}
$$

Where:

$\mathrm{D}=$ frost penetration depth $(\mathrm{m})$,

$\mathrm{AFI}=$ freezing index,

$\lambda=$ correction coefficient and depend on soil texture

The depth of frost penetration can be estimated with a reasonable accuracy from air freezing index only if the effect of the other variables can be minimized. The relation between the maximum frost penetration and the freezing index was studied in [7]. Different relationships were developed to predict the maximum frost penetration from the freezing index based on the type of surface and whether it is covered with snow or not. In [9] the temperature data collected from road weather information system (RWIS) installed in northern Ontario was used to predict frost depth. The relationship between cumulative freezing degree days and frost depth was found to be as shown in Equation (7).

$$
F D=5.537 \sqrt{T I}
$$

Where:

FD $=$ Frost depth $(\mathrm{cm})$

$\mathrm{TI}=\Sigma\left(\mathrm{T}_{\text {air, mean }}+5.31^{\circ} \mathrm{C}\right)\left(\mathrm{C}^{\circ}\right.$. Days $)$,

$\mathrm{T}_{\mathrm{air} \text {, mean }}=$ Average daily air temperature $\left(\mathrm{C}^{\circ}\right)$

Stefan equation is one of the first known theoretical formulas to calculate frost penetration. The Stefan equation, which is presented in Equation (8), is derived from the fundamental equation of heat flow and storage [10].

$$
D=\sqrt{\frac{48 k F}{L}}
$$

Where:

$\mathrm{D}=$ depth of frost penetration $(\mathrm{ft})$

$\mathrm{K}=$ thermal conductivity (Btu ${ }^{1}$ 's per $\mathrm{ft}^{2}$ per degree Fahrenheit per $\mathrm{ft}$ per hr.)

$\mathrm{F}=$ freezing index $\left({ }^{\circ} \mathrm{F}\right.$. Days $)$

$\mathrm{L}=$ volumetric heat of latent fusion $\left(\right.$ Btu's per $\left.\mathrm{ft}^{3}\right)$

An expression for frost penetration which designated the modified Berggren formula was developed in [11]. Equation (9) is presented this developed equation.

$$
z=\lambda \sqrt{\frac{48 k F}{L}}
$$

The units in two above equations are the same; $\lambda$ is a dimensionless correction coefficient depending upon the thermal ratio and fusion parameter [3].

In [5] a simple predictive tool was developed to calculate a new correction coefficient depending upon the thermal ratio and fusion parameter. The new correction coefficient can be used in follow up calculations to estimate the depth of frost penetration for both uniform and layered soils in frost-effected regions to evaluate the performance of pavement. The temperatures of the pavement surface during the frost period are decisive for calculating the depth of frost penetration in a road. Temperature measurements of the surface, however, are usually not available, so that the exact calculation of a surface freezing index is not possible. Therefore, a relationship between the freezing indices of the surface and of the air is required as shown in Equation (10).

Where:

$$
n=\frac{F I_{s}}{F I_{a}}
$$

$\mathrm{FI}_{\mathrm{s}}=$ surface freezing index,

$\mathrm{FI}_{\mathrm{a}}=$ air freezing index

Different conversion factors based on the types of surface for both freezing and thawing conditions was proposed by Corps of Engineers (Table 2).

\footnotetext{
${ }^{1} \mathrm{Btu}$ : British thermal unit (the quantity of heat required to raise the temperature of 1 pound (Ib) of water $1^{\circ} \mathrm{F}$ at about $40^{\circ} \mathrm{F}$.
} 
International Advanced Research Journal in Science, Engineering and Technology

Vol. 7, Issue 5, May 2020

TABLE I n-FACTORS FOR FREEZE AND THAW [17]

\begin{tabular}{lll}
\hline Type of surface & For freezing conditions & For thawing conditions \\
\hline Snow surface & 1.0 & --- \\
Portland-cement concrete & 0.75 & 1.5 \\
Bituminous pavement & 0.7 & 1.6 to 2 \\
Bare soil & 0.7 & 1.4 to 2 \\
Shaded surface & 0.9 & 1.0 \\
Turf & 0.5 & 0.8 \\
Tree-covered & 0.3 & 0.4 \\
\hline
\end{tabular}

The accuracy of different analytical and semi-empirical frost depth prediction models including Stefan model, Modified Berggren model and Chisholm and Phang empirical model was tested and a general empirical model that requires thermal conductivity and average air temperature as inputs was developed by Rajabei and Baladi in [12]. This general model is expressed by Equation (11).

$$
P=(-0.45 K+1.9614) \times C F I^{(0.0913 K+0.4143)}
$$

Where:

P: frost depth (in)

$\mathrm{K}$ : thermal conductivity of soil (Btu/ft.hr. $\left.{ }^{\circ} \mathrm{F}\right)$

CFI: cumulative freezing index $\left({ }^{\circ} \mathrm{F}\right.$. Day)

In this paper, two models; Modified Berggren equation and Rajaei \& Baladi formula are used to calculate frost penetration depth. Then, results obtained from two models are compared together to reach reliable values of frost depth for Salang highway.

Summary of all data and properties required for calculation of frost penetration depth by modified Berggren equation is presented in Table 6 .

TABLE 2 DATA AND PROPERTIES REQUIRED FOR FROST PENETRATION DEPTH

\begin{tabular}{|c|c|c|c|}
\hline Symbol & Description & Unit & Source \\
\hline $\mathrm{Z}$ & Frost penetration depth & $\mathrm{ft}$ & from developed models \\
\hline $\mathrm{F}$ & Air freezing index & ${ }^{\circ} \mathrm{F}$. Day & $F=\left[\left(\Sigma T_{\text {month }}\right) * N i\right]$ \\
\hline $\mathrm{K}$ & Thermal conductivity of material & Btu/ft.hr. ${ }^{\circ} \mathrm{F}$ & given from charts, $K=f(\gamma, \omega)$ \\
\hline $\mathrm{L}$ & volumetric heat of latent fusion & $\mathrm{Btu} / \mathrm{ft}^{3}$ & $L=1.434 \omega \gamma_{d}$ \\
\hline $\mathrm{n}$ & Conversion factor & Dimensionless & from tables \\
\hline$\lambda$ & Correction coefficient & Dimensionless & given from charts, $\lambda=f(\mu, \alpha)$ \\
\hline$\mu$ & Fusion parameter & Dimensionless & $\mu=V_{s}\left(\frac{C}{L}\right)$ \\
\hline$\alpha$ & Thermal ratio & Dimensionless & $\alpha=V_{0} / V_{s}$ \\
\hline $\mathrm{V}_{0}$ & $\begin{array}{l}\text { Initial temperature of soil with respect } \\
\text { to } 32^{\circ} \mathrm{F}\end{array}$ & ${ }^{\circ} \mathrm{F}$ & $V O=M A T-32^{\circ} \mathrm{F}$ \\
\hline $\mathrm{V}_{\mathrm{s}}$ & $\begin{array}{l}\text { Average surface temperature with } \\
\text { respect to } 32^{\circ} \mathrm{F}\end{array}$ & ${ }^{\circ} \mathrm{F}$ & $V s=n F / t$ \\
\hline MAT & Mean annual temperature & ${ }^{\circ} \mathrm{F}$ & from climate data \\
\hline $\mathrm{T}$ & Length of freezing season & Day & from climate data \\
\hline $\mathrm{C}$ & Volumetric heat capacity & $\mathrm{Btu} / \mathrm{ft}^{3} .^{\circ} \mathrm{F}$ & $C=\gamma_{d}\left(0.17+\frac{0.75 w}{100}\right)$ \\
\hline$\gamma_{\mathrm{d}}$ & Dry density of soil & $\mathrm{lb} / \mathrm{ft}^{3}$ & from soil testing \\
\hline$\omega$ & Moisture content & $\%$ & from soil testing \\
\hline
\end{tabular}




\section{International Advanced Research Journal in Science, Engineering and Technology}

Vol. 7, Issue 5, May 2020

\section{RESULTS AND DISCUSSION}

In this section, all required parameters for frost penetration depth prediction based on Modified Berggren equation are evaluated and calculated. First, freezing index for Salang area is obtained as discussed in previous section.

Since, 30 years of climate record is not available in Salang highway, temperature data for the last 10 year-period was collected and freezing index for the coldest winter was calculated. The minimum, maximum and average temperature data for last 10 years in Salang area is summarized in Table 3.

TABLE 3 TEMPERATURE DATA FOR THE LAST 10 YEARS IN SALANG [15]

\begin{tabular}{lllllllllll}
\hline Year & $\mathbf{2 0 1 1}$ & $\mathbf{2 0 1 2}$ & $\mathbf{2 0 1 3}$ & $\mathbf{2 0 1 4}$ & $\mathbf{2 0 1 5}$ & $\mathbf{2 0 1 6}$ & $\mathbf{2 0 1 7}$ & $\mathbf{2 0 1 8}$ & $\mathbf{2 0 1 9}$ & $\mathbf{2 0 2 0}$ \\
\hline Min & $-10^{\mathrm{a}}$ & -15 & -11 & -9 & -7 & -5 & -9 & -4 & -5 & -10 \\
Average & -6 & -9 & -7 & -5 & -3 & -1 & -5 & -1 & 0 & -3 \\
Max & -1 & -4 & -1 & 1 & 1 & 4 & 0 & 3 & 2 & 0 \\
\hline
\end{tabular}

a. unit of temperature is Celsius

According to the above data, the coldest winter was in 2012. Therefore, monthly temperature data for this year is summarized in Table 4

TABLE 4 MONTHLY TEMPERATURE DATA FOR 2012 IN SALANG [15]

\begin{tabular}{ccccccccccccc}
\hline Month & Jan & Feb & Mar & Apr & May & Jun & Jul & Aug & Sep & Oct & Nov & Dec \\
\hline Min & -12 & -15 & -5 & 4 & 8 & 11 & 14 & 14 & 10 & 4 & -1 & -7 \\
Average & -8 & -9 & -1 & 7 & 12 & 16 & 19 & 19 & 14 & 8 & 2 & -3 \\
Max & -3 & -4 & 3 & 11 & 16 & 21 & 24 & 24 & 19 & 13 & 7 & 2 \\
\hline
\end{tabular}

In order to find the correction coefficient in this study, first, two required parameters (thermal ratio and fusion parameter) were calculated based on the climate properties of the study are and then a simple predictive tool in [5] was used.

Another climate data required for calculation of frost depth is mean annual temperature (MAT). This parameter can be found out from Table 4 for 2012 as coldest year which is calculated $6.33\left({ }^{\circ} \mathrm{C}\right)$ (or MAT $=43.39{ }^{\circ} \mathrm{F}$ ).

Moreover, freezing season in which the air temperature is equal to zero or less than zero (Celsius) took 122 days in Salang area in 2012.

To study physical properties of soils including dry density and moisture content, relevant data were obtained from a soil investigation. The soil investigation has been performed along the road pavement in several locations by digging trial pits, field density testing, sampling and laboratory testing. These trial pits were located in both north and south of Salang highway. In this work, soil data of 18 trial pits has been extracted and used. For determination of in-situ dry density and moisture content of soils, field testing was carried out by two different methods; sand cone method (ASTM D1556) [21] and nuclear method (ASTM D2922) [20].

In addition, particle size analysis and Atterberg testing were performed on retrieved soil samples in the laboratory according to standards AASHTO T88 and T89 [23], [24] and soil engineering classification was done for each soil sample according to AASHTO M145 [22]. The results of field testing and laboratory analysis are summarized in Table 5.

According to the result of laboratory analysis, the predominant soils are gravels and sands with low plasticity behaviour in the study area. 
International Advanced Research Journal in Science, Engineering and Technology

Vol. 7, Issue 5, May 2020

TABLE 5 PHYSICAL PROPERTIES AND AASHTO CLASSIFICATION OF SOILS

\begin{tabular}{lcccc}
\hline Trial Pit no. & Station & $\begin{array}{c}\text { Soil Class } \\
(\text { AASHTO) }\end{array}$ & $\begin{array}{c}\text { Dry Density } \\
\left.\mathbf{( l b / f t}^{\mathbf{3}}\right)\end{array}$ & $\begin{array}{c}\text { Moisture Content } \\
(\mathbf{\%})\end{array}$ \\
\hline 28 & $32+700$ & A-4 & 109.75 & 4.0 \\
30 & $33+350$ & A-1-a & 106.25 & 3.4 \\
31 & $33+730$ & A-1-b & 107.56 & 3.5 \\
33 & $34+220$ & A-1-a & 126.60 & 6.5 \\
35 & $34+920$ & A-4 & 110.81 & 3.8 \\
37 & $35+760$ & A-2-4 & 114.43 & 2.6 \\
38 & $36+080$ & A-1-a & 109.75 & 3.7 \\
39 & $36+620$ & A-1-a & 118.11 & 5.2 \\
41 & $37+130$ & A-1-a & 116.24 & 3.3 \\
43 & $38+102$ & A-1-b & 113.87 & 3.6 \\
$43-$ A-C & $38+250$ & A-1-b & 124.23 & 2.5 \\
$45-A-C$ & $39+200$ & A-1-a & 128.66 & 4.0 \\
$46-A-C$ & $39+560$ & A-1-b & 120.61 & 4.1 \\
78 & $58+640$ & A-1-b & 98.64 & 8.2 \\
79 & $58+820$ & A-1-a & 127.73 & 4.2 \\
85 & $60+680$ & A-1-a & 129.98 & 5.3 \\
86 & $61+080$ & A-1-b & 129.41 & 4.5 \\
88 & $61+880$ & A-1-b & 131.29 & 4.6 \\
\hline
\end{tabular}

According to the climate data and Equation (7) which were discussed in the previous section, air freezing index for Salang area is calculated in Table 7.

TABLE 6 CALCULATION METHOD FOR FREEZING INDEX IN SALANG AREA

\begin{tabular}{lllllll}
\hline $\begin{array}{l}\text { Month in } \\
\text { freezing }\end{array}$ & Days & $\begin{array}{l}\text { Temperatures } \\
\left({ }^{\circ} \mathbf{F}\right)\end{array}$ & $\begin{array}{l}\text { Temperatures } \\
\left({ }^{\circ} \mathbf{c}\right)\end{array}$ & $\begin{array}{l}\mathbf{T}|(32-\mathbf{T})| \\
\left({ }^{\circ} \mathbf{F}\right)\end{array}$ & $\begin{array}{l}\text { Monthly } \\
\text { Freezing index }\end{array}$ & Freezing index \\
\hline January & 31 & 17.6 & -8 & 14.4 & $14.4 \times 31$ & 446.4 \\
February & 29 & 15.8 & -9 & 16.2 & $16.2 \times 29$ & 469.8 \\
March & 31 & 30.2 & -1 & 1.8 & $1.8 \times 31$ & 55.8 \\
December & 31 & 26.6 & -3 & 5.4 & $5.4 \times 31$ & 167.4 \\
\hline Total & $\mathbf{1 2 2}$ days & & & & $\mathbf{1 1 3 9 . 4}\left({ }^{\circ} \mathbf{F}\right.$. day) \\
\hline
\end{tabular}

All data required for frost penetration depth calculation were put in a formulated spread sheet and then computations were conducted based on modified Berggren formula. In addition, calculation of frost penetration depth was done based on general model proposed by Rajaei and Baladi.

In frost penetration depth calculations for Salang area, surface type was considered as bituminous pavement. Therefore, conversion factor ( $\mathrm{n}$ ) was 0.7 for ground surface covered by bituminous road pavement as per Table 2 .

The calculated frost penetration depth obtained by two different methods (modified Berggren equation and Rajaei \& Baladi equation) are presented in Table 8. 
Vol. 7, Issue 5, May 2020

The calculation results shows that predicted frost depth obtained by Modified Berggren formula is more than predicted frost depth calculated by Rajaei \& Baladi formula. Whereas, field measurements of frost depth are unavailable for the study area, we are not able to verify the calculated frost depth therefore predicted values of frost depth based on Modified Berggren formula is considered as Maximum Predicted Frost Depth for Salang area.

TABLE 7 PARAMETERES FOR FROST PENETRATION DEPTH BY TWO DIFFERENT METHODS

\begin{tabular}{|c|c|c|c|c|c|}
\hline Location ID & $\begin{array}{l}\mathbf{L} \\
\mathrm{Btu} / \mathrm{ft}^{3}\end{array}$ & $\begin{array}{l}\mathbf{K} \\
\text { Btu/ft.hr. }{ }^{\circ} \mathrm{F}\end{array}$ & $\begin{array}{l}\lambda \\
\cdots\end{array}$ & $\begin{array}{l}\mathbf{Z} \\
\text { From ModB } \\
(\mathrm{cm})\end{array}$ & $\begin{array}{l}\mathbf{z} \\
\text { From R\&B } \\
(\mathrm{cm})\end{array}$ \\
\hline 28 & 629.52 & 0.71 & 0.65 & 130.19 & 121.54 \\
\hline 30 & 518.04 & 0.56 & 0.62 & 121.57 & 114.91 \\
\hline 31 & 539.86 & 0.625 & 0.64 & 129.87 & 117.76 \\
\hline 33 & 1180.08 & 1.4 & 0.71 & 145.84 & 153.54 \\
\hline 35 & 603.82 & 0.6 & 0.63 & 118.44 & 116.66 \\
\hline 37 & 426.64 & 0.7 & 0.59 & 142.53 & 121.09 \\
\hline 38 & 582.30 & 0.7 & 0.635 & 131.30 & 121.09 \\
\hline 39 & 880.75 & 1.1 & 0.68 & 143.32 & 139.46 \\
\hline 41 & 550.08 & 0.8 & 0.615 & 139.87 & 125.60 \\
\hline 43 & 587.84 & 0.825 & 0.635 & 141.87 & 126.73 \\
\hline $43 \mathrm{~A}-\mathrm{C}$ & 445.37 & 0.9 & 0.585 & 156.83 & 130.17 \\
\hline $45 \mathrm{~A}-\mathrm{C}$ & 738.02 & 1.2 & 0.65 & 156.31 & 144.15 \\
\hline $46 \mathrm{~A}-\mathrm{C}$ & 709.12 & 0.95 & 0.655 & 142.98 & 132.47 \\
\hline 78 & 1159.84 & 0.75 & 0.75 & 113.74 & 123.33 \\
\hline 79 & 769.28 & 1.2 & 0.655 & 154.28 & 144.15 \\
\hline 85 & 987.84 & 1.45 & 0.685 & 156.51 & 155.88 \\
\hline 86 & 835.10 & 1.3 & 0.67 & 157.65 & 148.85 \\
\hline 88 & 866.02 & 1.35 & 0.67 & 157.76 & 151.20 \\
\hline
\end{tabular}

a. Modified Berggren Equation

b. Rajaei \& Baladi Formula

Based on the results from modified Berggren formula, average frost penetration depth in south of Salang highway is around 4.55 foot $(138 \mathrm{~cm})$. But average frost penetration depth in north of Salang highway is around $4.86 \mathrm{foot}(148 \mathrm{~cm})$. The average of physical and thermal properties of soil in north and south of Salang highway is compared in Table 9. Also this table shows the average of calculated frost penetration depth in both parts of the highway.

TABLE 8 AVERAGE FROST PENETRATION DEPTHS IN NORTH AND SOUTH SALANG HIGHWAY

\begin{tabular}{lllllll}
\hline $\begin{array}{l}\text { Average } \\
\text { properties of soils }\end{array}$ & $\begin{array}{l}\text { Dry density } \\
\text { of soil } \\
\mathrm{lb} / \mathrm{ft}^{3}\end{array}$ & $\begin{array}{l}\text { Moisture } \\
\text { content }\end{array}$ & $\mathbf{C}$ & $\mathbf{L}$ & $\mathbf{K}$ & $\begin{array}{l}\text { Frost depth } \\
\text { (average) }\end{array}$ \\
\hline South Salang & 115.91 & 3.86 & 23.18 & 645 & 0.85 & 4.5 \\
North Salang & 123.41 & 5.36 & 24.68 & 924 & 1.21 & 4.8 \\
\hline
\end{tabular}




\section{International Advanced Research Journal in Science, Engineering and Technology}

Vol. 7, Issue 5, May 2020

As per above table, in north of Salang soils have more dry density and moisture content than south part, it causes more soil thermal properties. This difference leads to deeper frost penetration depth in the north part, consequently. In order to evaluate correlation between dry density of soil and predicted frost depth, a statistical power function was applied to plot the trend line. The power equation between the above two parameters is depicted in Figure 2.

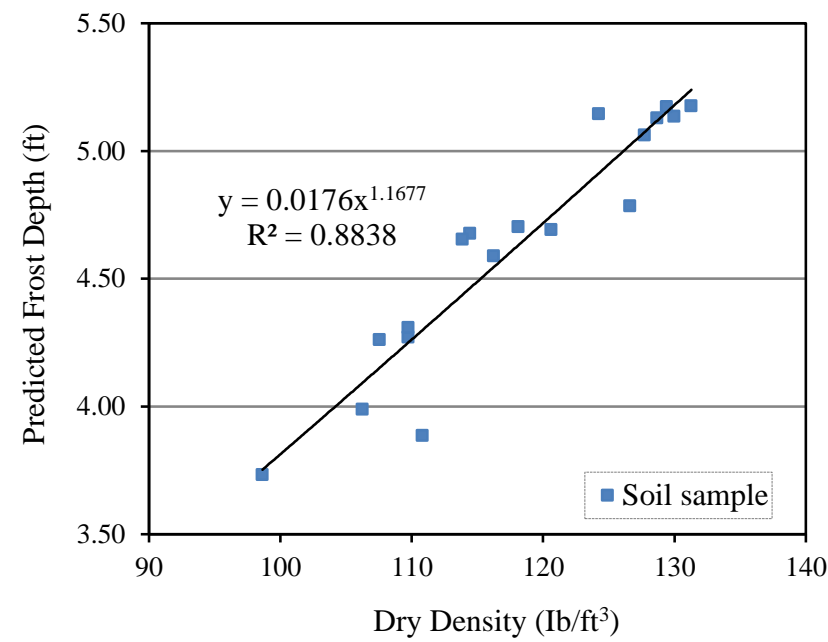

Fig. 2 Correlation between predicted frost depth and dry density of soils

Equation (12) was obtained from above figure as correlation formula. It is easily possible to predict maximum frost depth in Salang area by applying dry density of soil into this equation.

Which:

$$
F D=0.0176 \times D_{d}^{1.1677}
$$

$\mathrm{FD}=$ Predict frost depth $(\mathrm{ft})$

$\mathrm{D}_{\mathrm{d}}=$ Dry density $\left(\mathrm{lb} / \mathrm{ft}^{3}\right)$

The coefficient of determination $\left(\mathrm{R}^{2}\right)$ was obtained 0.88 in Figure 2. This value of $\mathrm{R}^{2}$ indicates that above equation could predict frost depths relatively accurate in other areas having similar geographic and climate condition with Salang area.

\section{CONCLUSION}

In this study, all required data for frost penetration depth calculation were collected and evaluated. There was no experience and analytical information in the available sources regarding frost penetration depth in Salang area before this study. After reviewing the literatures, modified Berggren and Rajabei \& Baladi formulas were selected for frost depth prediction. Modified Berggren equation is an analytical and semi-empirical model in purpose of frost penetration depth calculation because it considers both climate condition and also thermal properties of ground material. On the other hand, Rajaei \& Baladi model is a revised empirical model which requires only cumulative freezing index and thermal conductivity of soil as inputs.

According to the climate data in Salang area, coldest winter was in 2012 and length of freezing season in this year was 122 days. Air freezing index was calculated based on proposed equation and it was obtained 1139.4 ( ${ }^{\circ} \mathrm{F}$. day). The result of computations shows that predicted frost depth is more where modified Berggren equation was used. Hence, calculated frost depth resulted from Modified Berggren formula is suggested to be considered as maximum predicted frost depth for Salang highway. Average frost penetration depth in south of Salang highway is around 4.55 foot $(138 \mathrm{~cm})$ but it is around 4.86 foot $(148 \mathrm{~cm})$ in north of the highway. It is concluded that more dry density and more thermal properties of soils in north of Salang highway is caused to deeper frost penetration depth in comparison with the south part.

According to the proposed correlation formula in this paper, it is possible to predict maximum frost depth in Salang area by applying dry density of soil. The coefficient of determination of this correlation indicates that the equation could predict frost depths relatively accurate in other areas having similar geographic and climate condition with Salang area. 


\section{International Advanced Research Journal in Science, Engineering and Technology}

Vol. 7, Issue 5, May 2020

Field temperature measurement is necessary to be carried out by special devices in the base and in the sub-grade of the Salang highway. In addition, field measurement of frost depth should be considered by special instruments such as tubes with fluorescence or bubble tube. Predicted values obtained in this study should be examined and compared with those field measurements.

\section{REFERENCES}

[1]. J. E. Bowles, "Foundation Analysis and Design," 5th ed., ISBN 0-07-912247-7 (set), McGraw Hill Companies Inc., 1997.

[2]. R. W. Day, "Foundation Engineering Handbook," McGraw Hill companies Inc., ASCE Press, 2006.

[3]. E.J. Yoder, and M.W. Witczak, "Principles of pavement design," 2nd ed. New York: Wiley, 1975

[4]. S. Mc Koewn, J.I. Klark, and D. Matheson, "Frost Penetration and Thermal Regime in Dry Gravel," Journal of Cold Regions Engineering.2:111-123, 1988.

[5]. A. Bahadori, S. Zendehboudi, G. Zahedi, and M.Bahadori, "Estimation of the depth of frost penetration in both uniform and layered soils in frost-affected regions," International Journal of Pavement Engineering, 15:7, 599-605, 2014.

[6]. P.M. Steuer, and J.H. Crandell, "Comparison of methods used to create estimate of air freezing index," Journal of Cold Regions Engineering.9:64-75, 1995.

[7]. G. H. Argue, and B. B. Denyes, "Estimating the Depth of Pavement Frost and Thaw Penetrations," Transportation Research Record, Volume 497, p 18- 30, 1974.

[8]. L.E. Sommers, C.M. Gilmour, R.E. Wildung, and S.M. Beck, "The Effect of Water Potential on Decomposition Processes in Soils, in Water Potential Relations in Soil Microbiology," Spec.publ.9.97-117, 1981

[9]. K. Huen, S. Tighe, B. Mills, and M. Perchanok," Development of Tolls for Improved Spring Load Restriction Policies in Ontario," The Annual conference of the Transportation Association of Canada (TAC), Charlottetown, Prince Edward Island, 2006.

[10]. H. Soliman, S. Kass , and N. Fleury, “ A Simplified Model to Predict Frost Penetration for Manitoba Soils," Annual conference of the transportation association of Canada, Toronto, Ontario, 2008

[11]. J. H. Aldrich, and H. Paynter, "Analytical Studies of Freezing and Thawing of Soils," U.S. Army Corps of engineers, Frost investigations, 1953.

[12]. P. Rajaei, and G. Y. Baladi, "Frost depth-A General prediction Model," 94th Transportation Research Board Annual Meeting, Washington D.C., 2015.

[13]. W. P. Berggren, "Prediction of temperature distribution in frozen soils," Transactions, American Geophysical Union, Part III, 1943.

[14]. G. Schnitter, and R.Zobrist, "Freeing Index and Frost Penetration in Switzerland," Laboratories for hydraulic research and soil mechanics annexed to the Swiss Federal institute of technology, Zurich, p 315-320, 1962.

[15]. https://www.worldweatheronline.com/salang-weather-averages/baghlan/af.aspx

[16]. U.S. Army Corps of Engineers, "Bearing capacity of soils,” EM 1110-1-1905, Department of the Army, Washington, DC 20314-1000, 1992.

[17]. Joint Department of the Army and Air Force UAS, "Calculation Methods for Determination of Depths of Freeze and Thaw in soils," Technical Manual TM 5-852-6/AFR 88-19, Volume 6 (1988), UFC 3-130-06. 2004.

[18]. U. S. Army and U.S. Air Force, "Arctic and Subarctic Construction Calculation Methods for Determination of Depths of Freeze and Thaw in Soils.” Technical Manual: TM5-852-6/AFM, 1966.

[19]. U.S. Army corps of Engineers, "Engineering and Design, Pavement Design for Frost Conditions," EM-1110-345-306, 1958.

[20]. ASTM, "Standard Test Methods for Density of Soil and Soil-Aggregate in Place by Nuclear Methods (Shallow Depth) (ASTM D2922)," 2005.

[21]. ASTM, "Standard Test Method for Density and Unit Weight of Soil in Place by Sand-Cone Method (ASTM D1556)," Annual Book of Standards, 2010.

[22]. AASHTO, "Standard Specification for Classification of Soils and Soil-Aggregate Mixtures for Highway Construction Purposes (AASHTO M145)," 1991.

[23]. AASHTO, "Standard Method of Test for Particle Size Analysis of Soils (AASHTO T 88)," 2010

[24]. AASHTO, "Standard Method of Test for Determining the Liquid Limit of Soils (AASHTO T 89)," 2010. 